\title{
PENGARUH PROPORSI MAIZENA:SLURRY DAN LAMA PEMASAKAN TERHADAP KARAKTERISTIK LEMPOK WALUH
}

\section{The Effect of Maize Proportion: Slurry and Time of Cooking to Pumpkin Lempok Characteristics}

\author{
Aninditya Puspitasari, Wahono Hadi Susanto, Novita Wijayanti \\ Jurusan Teknologi Hasil Pertanian, FTP Universitas Brawijaya, Malang \\ JI. Veteran, Malang 65145 \\ *Penulis Korespondensi, email: anindityapuspitasari@gmail.com
}

\begin{abstract}
ABSTRAK
Salah satu produk olahan waluh yang berpotensi untuk dikembangkan adalah lempok. Lempok yang baik mempunyai konsistensi gel yang baik, yang dapat dipengaruhi oleh kandungan pektin dan asam pada buah maupun penambahan pengental. Pada penelitian ini digunakan maizena sebagai bahan pengental. Selain itu faktor penting yang harus diperhatikan yaitu lama pemasakan yang akan memodifikasi sifat fisik bahan. Penelitian ini bertujuan untuk mengetahui pengaruh dan interaksi proporsi maizena dan lama pemasakan terhadap karakteristik lempok waluh. Penelitian ini menggunakan metode Rancangan Acak Kelompok (RAK) faktorial dua faktor. Faktor I adalah proporsi maizena dengan slurry (M) yang terdiri tiga level (1:40; 2:40; 3:40), dan faktor II adalah lama waktu pemasakan (L) yang terdiri dari tiga level (120 menit; 150 menit; 180 menit). Lempok waluh terbaik yaitu pada perlakuan proporsi maizena:slurry sebanyak 3:40 dengan lama pemasakan 150 menit.
\end{abstract}

Kata Kunci: lama pemasakan, lempok, maizena, waluh,

\section{ABSTRACT}

Lempok is one of processed products of pumpkin is that is potential to be developed. The good product of Lempok have good gel consistency, which can be affected by pectin and acid contents in the fruit as well as the thickening. In this study used maize as thickening agent. In addition, an important factor that must be considered is the length of cooking, where the cooking process will modify the physical properties of the material. This research used Factorial Randomized Block Design (RBD) two factors. First factor is the proportion of maize with slurry $(M)$ consisting of three levels (1:40; 2:40; 3:40), and the second factor is time of cooking (L) consisting of three levels (120 minutes, 150 minutes, 180 minutes). The best pumpkin lempok is in the treatment of maize:slurry proportion of 3:40 with the length of cooking 150 minutes.

Keywords: lempok, maize, pumpkin, time of cooking

\section{PENDAHULUAN}

Indonesia merupakan negara agraris yang kaya akan sumber daya alam hayati, salah satunya yaitu komoditas labu kuning atau sering disebut dengan waluh (Cucurbita $s p$.). Jumlah ketersediaan waluh di Indonesia relatif tinggi, dimana menurut data dari Badan Pusat Statistik, produksi waluh di Indonesia pada tahun 2011 produksinya mencapai 428.197 ton (Kusumawati, 2013). Namun, hal ini tidak diimbangi dengan tingkat konsumsi waluh, dimana tingkat konsumsinya masih sangat rendah yaitu kurang dari $5 \mathrm{~kg}$ per kapita per tahun (Hayati, 2006). Waluh mempunyai kandungan nutrisi yang cukup lengkap diantaranya yaitu karbohidrat, protein, lemak, kalsium, fosfor, besi, vitamin A, vitamin B, air, vitamin C (Hendrasty, 2011). 
Lempok yang baik mempunyai konsistensi gel yang baik, dimana konsistensi tersebut dipengaruhi oleh kandungan pektin dan asam yang terdapat pada buah maupun adanya penambahan bahan pengental. Pembentukan gel dipengaruhi oleh adanya pektin, gula, asam, dan air. Gel dapat terbentuk jika kandungan pektin 1\%, gula 58-75\% dan pH 2.8-3.5 (Grosch dan Belitz, 2009). Pada waluh mengandung pati $6.6 \%$ dan pektin sebesar $0.63 \%$ (Yuliani dkk, 2003). Pembentukan gel juga dapat disebabkan oleh adanya pengental. Penambahan jumlah pengental tergantung dari jenis bahan baku yang digunakan. Salah satu bahan pengental tambahan yang sering digunakan yaitu maizena.

Tujuan dari penelitian ini yaitu untuk mengetahui pengaruh proporsi maizena dengan slurry dan lama waktu pemasakan terhadap karakteristik lempok waluh, mengetahui pengaruh interaksi proporsi maizena dengan slurry dan lama waktu pemasakan terhadap karakteristik lempok waluh dan mengetahui perlakuan terbaik proporsi maizena dengan slurry dan lama waktu pemasakan pembuatan lempok waluh

\section{BAHAN DAN METODE}

\section{Bahan}

Bahan yang digunakan dalam proses pembuatan lempok waluh yaitu waluh yang didapat dari pedagang di Pakisaji, maizena (merk RRT Xing Mao), gula pasir (merk Rose Brand), margarin (merk Simas), potasium sorbat, dan natrium metabisulfit. Bahan yang digunakan untuk analisis adalah DPPH $0.2 \mathrm{mM}$ dalam metanol, metanol, etanol $96 \%, \mathrm{NaOH}$ $0,1 \mathrm{~N}, \mathrm{H}_{2} \mathrm{C}_{2} \mathrm{O}_{4}, \mathrm{CaCO}_{3}$, reagen Anthrone, $\mathrm{H}_{2} \mathrm{SO}_{4}$ pekat $97 \%$, aseton, petroleum eter, dan $\mathrm{Na}_{2} \mathrm{SO}_{4}$.

\section{Alat}

Alat yang digunakan dalam pembuatan lempok waluh yaitu kompor gas (merk Rinnai), baskom, pisau, loyang, pengaduk kayu, sendok, timbangan (merk Electronic Kitchen Set WH$5 \mathrm{~K}$ ), plastik, blender (merk Advance BL-2).

Alat yang digunakan untuk analisis adalah neraca analitik (merk Denver M 310 USA), vortex-mixer (Model VM 2000), kompor listrik (merk Maspion), spektrofotometer dan kuvet (UNICO RRC UV 2100), oven listrik (WTB Binder), shaker waterbath (merk Memmert), color reader (merk Konica Minolta), desikator (merk Scoot Duran), bola hisap, statip, kertas saring halus dan glassware merk Pyrex (tabung reaksi, buret, erlenmeyer, gelas beaker, pipet volume, pipet tetes, gelas ukur, labu ukur, dan corong pemisah).

\section{Desain Penelitian}

Penelitian ini dirancang menggunakan metode Rancangan Acak Kelompok (RAK) faktorial dengan dua faktor. Faktor I adalah proporsi maizena dengan slurry (M) yang terdiri dari tiga level (1:40 g; 2:40 g; 3:40 g), dan faktor II adalah lama waktu pemasakan (L) yang terdiri dari tiga level (120 menit; 150 menit; 180 menit).

\section{Tahapan Penelitian}

Waluh dikupas dan dipotong kecil-kelcil lalu ditimbang $1 \mathrm{~kg}$. Kemudian dicuci bersih dan dilakukan blanching selama 5 menit kemudian dihaluskan dengan blender hingga didapatkan slurry. Slurry ditimbang sebanyak $1200 \mathrm{~g}$ lalu ditambahkan maizena sebanyak $30 \mathrm{~g} ; 60 \mathrm{~g}$; dan $90 \mathrm{~g}$, gula pasir $120 \mathrm{~g}$, dan margarin $36 \mathrm{~g}$. Dilakukan pemasakan selama 120 menit; 150 menit; dan 180 menit disertai dengan pengadukan suhu $80 \pm 2^{\circ} \mathrm{C}$. Lempok waluh dikemas dan disiterilisasi uap panas selama 15 menit.

\section{Prosedur Analisis}

Analisis dalam penelitian inii meliputi kadar air (Sudarmadji, 1997), total gula metode Anthrone (AOAC,1990), total karoten (Rodriguez dan Kimura, 2004), antioksidan (Hatano, et al., 1998), tekstur metode Tensile Strength Test, warna metode Colour Reader, dan organoleptik (warna, rasa, tekstur, aroma). 
Data hasil pengamatan dianalisis menggunakan metode Analysis of Variance (ANOVA) jika terdapat interaksi antara dua faktor dilakukan uji DMRT (Duncan Multiple Range Test) menggunakan selang kepercayaan $1 \%$ dan apabila terdapat beda nyata, maka dilakukan uji BNT (Beda Nyata Terkecil) dengan selang kepercayaan 1\%. Data hasil uji organoleptik dilakukan dengan uji Hedonic Scale Scoring. Sedangkan pemilihan perlakuan terbaik digunakan metode Multiple Atribut (Zeleny, 1982).

\section{HASIL DAN PEMBAHASAN}

\section{Bahan Baku}

Data analisis karakteristik bahan baku waluh ditunjukkan pada Tabel 1. Tabel 1 menunjukkan bahwa hasil analisis berbeda dengan literatur. Perbedaan tersebut dimungkinkan karena perbedaan umur waluh, keadaan iklim, tempat tumbuh, cara pemeliharaan dan pemanenan buah, serta penyimpanan buah pasca panen

Tabel 1 Data Hasil Analisis Bahan Baku Waluh Dibandingkan Pustaka

\begin{tabular}{lcc}
\hline \multicolumn{1}{c}{ Parameter } & \multicolumn{2}{c}{ Waluh } \\
\cline { 2 - 3 } & Hasil Analisis & Pustaka \\
\hline Kadar air $(\%)$ & 86.66 & $89.47^{\mathrm{a})}$ \\
Total gula $(\%)$ & 7.92 & $\left.8.89^{\mathrm{b}}\right)$ \\
Total asam $(\%)$ & 0.08 & $0.11^{\mathrm{c})}$ \\
Total karoten $(\mu \mathrm{g} / \mathrm{g})$ & 32.80 & $47.9^{\mathrm{d})}$ \\
Antioksidan $\mathrm{C}_{50}(\mathrm{ppm})$ & 3240 & $2860^{\mathrm{e})}$ \\
Kadar Pektin $(\%)$ & 0.58 & $0.63^{\mathrm{a})}$ \\
Warna : & & \\
Tingkat kecerahan $\left(\mathrm{L}^{*}\right)$ & 40.30 & $\left.48.70^{\mathrm{e}}\right)$ \\
Tingkat kemerahan $\left(\mathrm{a}^{*}\right)$ & 28.09 & $31.17^{\mathrm{e}}$ \\
Tingkat kekuningan $\left(\mathrm{b}^{*}\right)$ & 28.41 & $45.27^{\mathrm{e}}$ \\
\hline
\end{tabular}

Sumber: a) Yuliani, dkk. (2003), b) Murdiati dkk. (2008), c) Jaswir et. al,(2014)

d) Wahyuni dan Widjanarko (2015)

\section{Kadar Air Lempok Waluh}

Hasil sidik ragam menunjukkan bahwa perlakuan penambahan proporsi maizena:slurry, lama pemasakan, dan interaksi antar kedua faktor memberikan pengaruh yang sangat nyata terhadap rerata kadar air lempok waluh $(\alpha=0.01)$. Rerata kadar air lempok waluh akibat perlakuan penambahan proporsi maizena dan lama pemasakan dapat dilihat pada Gambar 1.

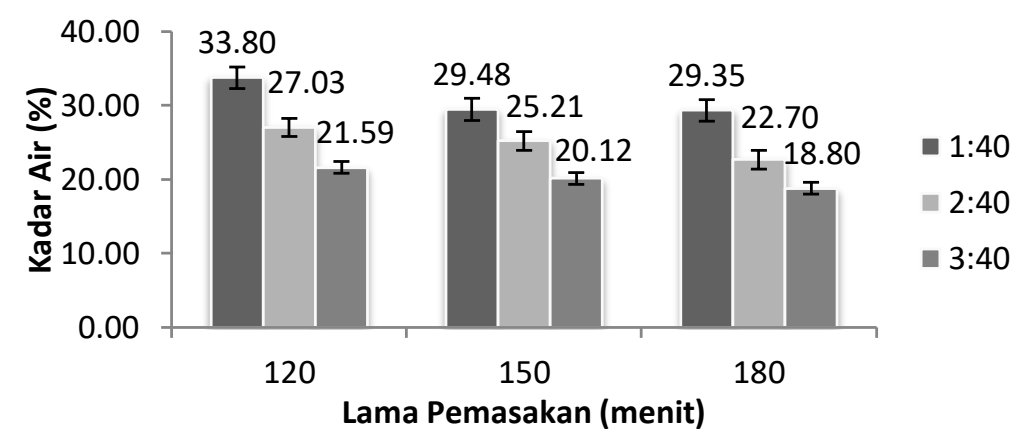

Gambar 1. Grafik Rerata Kadar Air (\%) Lempok Waluh Akibat Pengaruh Penambahan Proporsi Maizena:Slurry dan Lama Pemasakan Lempok

Perlakuan penambahan proporsi maizena dan lama pemasakan lempok terdapat interaksi, dimana seiring dengan penambahan proporsi maizena:slurry yang semakin banyak dan semakin lama waktu pemasakan maka kadar ai lempok akan cenderung semakin menurun. Hal ini dikarenakan oleh adanya penambahan maizena, dimana maizena 
merupakan pati jagung yang memiliki kemampuan dalam mengikat air yang ada di sekitarnya (Sari, 2011). Pati akan mengikat molekul air melalui ikatan hidrogen yang berasal dari maizena sehingga akan mengurangi jumlah air bebas pada bahan (Kusumawati dan Rukmi, 2013).

\section{Total Gula Lempok Waluh}

Hasil sidik ragam menunjukkan bahwa perlakuan penambahan proporsi maizena:slurry dan lama pemasakan memberikan pengaruh yang sangat nyata terhadap rerata kadar air lempok waluh ( $\alpha=0.01)$, sedangkan interaksi antara kedua faktor tidak memiliki pengaruh. Rerata kadar total gula lempok waluh akibat perlakuan penambahan proporsi maizena dapat dilihat pada Gambar 2.

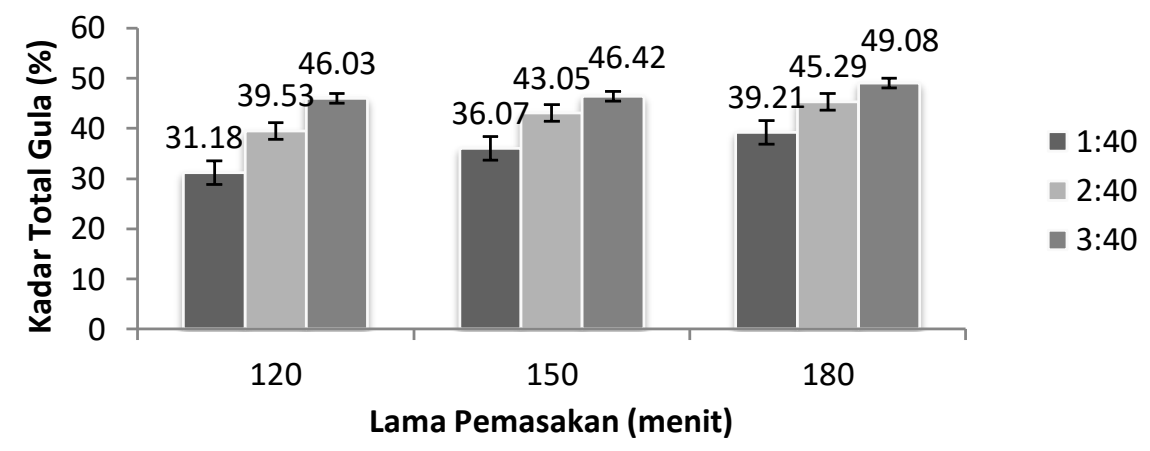

Gambar 2. Grafik Rerata Kadar Total Gula (\%) Lempok Waluh Akibat Pengaruh Penambahan Proporsi Maizena:Slurry dan Lama Pemasakan Lempok

Gambar 2 menunjukkan bahwa semakin banyak proporsi maizena yang ditambahkan maka kadar total gula pada lempok waluh akan meningkat. Hal ini dikarenakan maizena merupakan pati jagung, dimana pati ketika dipanaskan akan terhidrolisis menjadi gula. Sehingga semakin banyak pati yang ditambahkan, maka pati yang akan terhidrolisis menjadi gula juga semakin banyak (Imanningsih, 2012).

Selain itu, semakin lama pemasakan lempok waluh maka rerata kadar total gula pada lempok waluh akan cenderung semakin meningkat. Hal ini dapat dikarenakan karena selama proses pemasakan lempok waluh terjadi proses hidrolisis pati menjadi gula yang berasal dari waluh maupun maizena yang ditambahkan. Semakin lama proses pemasakan maka pati yang terhidrolisis akan semakin banyak (Jariyah dkk, 2017).

\section{Total Karoten Lempok Waluh}

Hasil sidik ragam menunjukkan bahwa perlakuan penambahan proporsi maizena:slurry dan lama pemasakan memberikan pengaruh yang sangat nyata terhadap rerata total karoten lempok waluh ( $\alpha=0.01)$, sedangkan interaksi antara kedua faktor tidak berpengaruh nyata.

Rerata kadar total karoten lempok waluh akibat perlakuan penambahan proporsi maizena dan lama pemasakan lempok yang berbeda dapat dilihat pada Gambar 3.

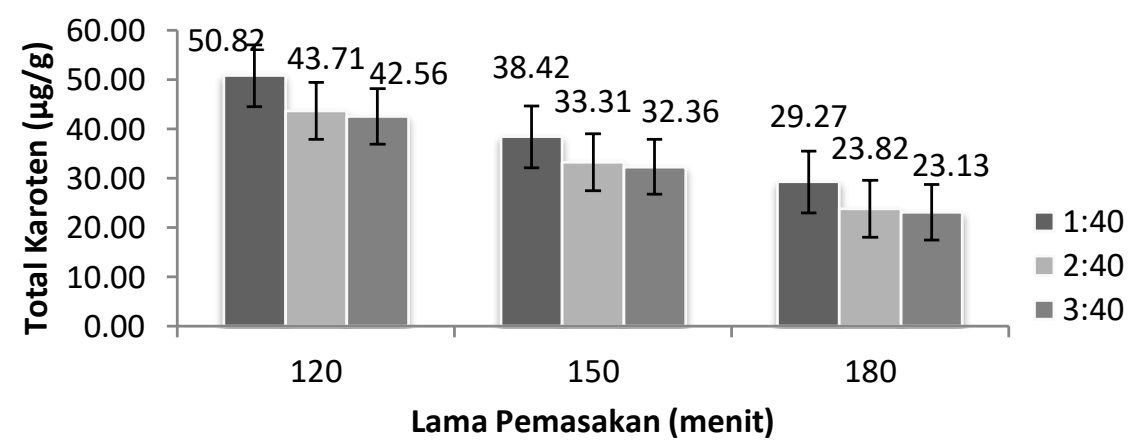

Gambar 3. Grafik Rerata Total Karoten $(\mu \mathrm{g} / \mathrm{g})$ Lempok Waluh Akibat Pengaruh Penambahan Proporsi Maizena:Slurry dan Lama Pemasakan Lempok 
Gambar 2 menunjukkan bahwa semakin banyak proporsi maizena:slurry yang maka total karoten pada lempok waluh akan menurun. Hal ini dikarenakan seiring dengan penambahan maizena yang semakin banyak, jumlah slurry waluh yang ditambahkan semakin sedikit. Selain itu maizena tidak mengandung karotenoid yang dapat menaikkan total karotenoid. Selain itu semakin lama proses pemasakan lempok, maka total karoten pada lempok waluh akan menurun dikarenakan pada pembuatan lempok waluh melibatkan proses pemanasan, dimana karoten dapat terdegradasi akibat proses oksidasi pada suhu tinggi (Histifarina, 2004) dam adanya isomerisasi termal yaitu isomerisasi trans-cis karotenoid (Madalena dkk, 2007).

\section{Antioksidan $\mathbf{I C}_{50}$ Lempok Waluh}

Hasil sidik ragam menunjukkan bahwa perlakuan lama pemasakan memberikan pengaruh yang sangat nyata terhadap rerata nilai $\mathrm{IC}_{50}$ lempok waluh $(\alpha=0.01)$, sedangkan perlakuan proporsi maizena:slurry yang berbeda serta interaksi antar kedua faktor tidak berpengaruh nyata.

Rerata nilai $I_{50}$ lempok waluh akibat perlakuan proporsi maizena:slurry dan lama pemasakan lempok yang berbeda dapat dilihat pada Gambar 4.

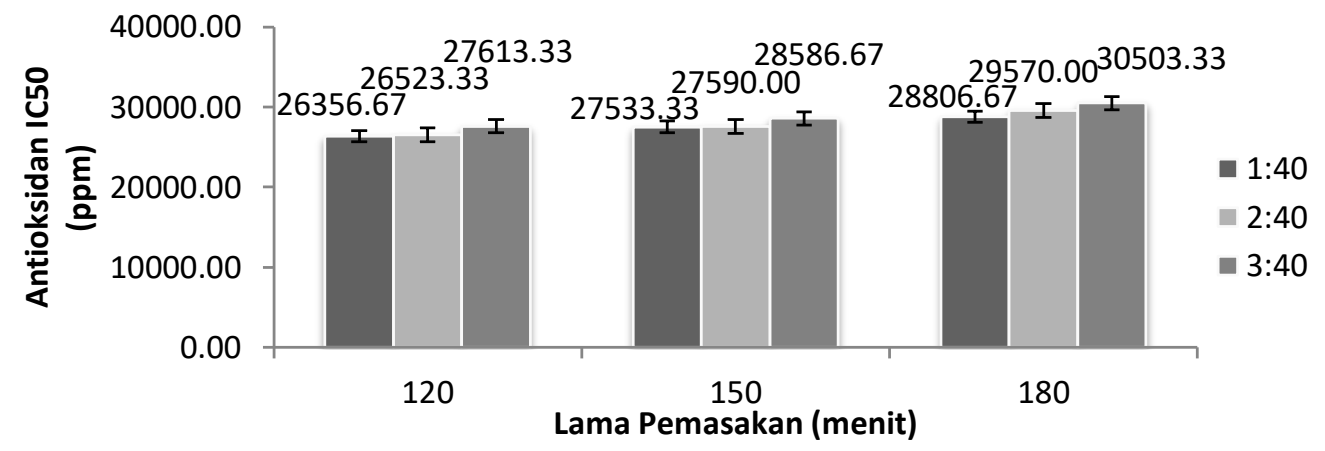

Gambar 4. Grafik Rerata Antioksidan $\mathrm{IC}_{50}$ (ppm) Lempok Waluh Akibat Pengaruh Penambahan Proporsi Maizena:Slurry dan Lama Pemasakan Lempok

Gambar 4 menunjukkan bahwa lama pemasakan memberikan pengaruh yang sangat nyata terhadap nilai $I_{50}$ lempok waluh, semakin lama proses pemasakan lempok, maka nilai $\mathrm{IC}_{50}$ pada lempok waluh akan meningkat. Hal ini dikarenakan pemanasan dengan waktu yang cukup lama dan suhu yang cukup tinggi lama dapat mempercepat oksidasi terhadap antioksidan yang terkandung dalam bahan yang dapat mengakibatkan penurunan aktivitas antioksidan (Husni dkk, 2014). Selain itu nilai $I_{50}$ lempok waluh juga dipengaruhi oleh kandungan total karoten yang terdapat di dalam bahan. Karoten termasuk dalam golongan karotenoid yang dapat berperan sebagai antioksidan. Grafik korelasi antara total karoten dan nilai aktivitas antioksidan $\mathrm{IC}_{50}$ dapat dilihat pada Gambar 5.

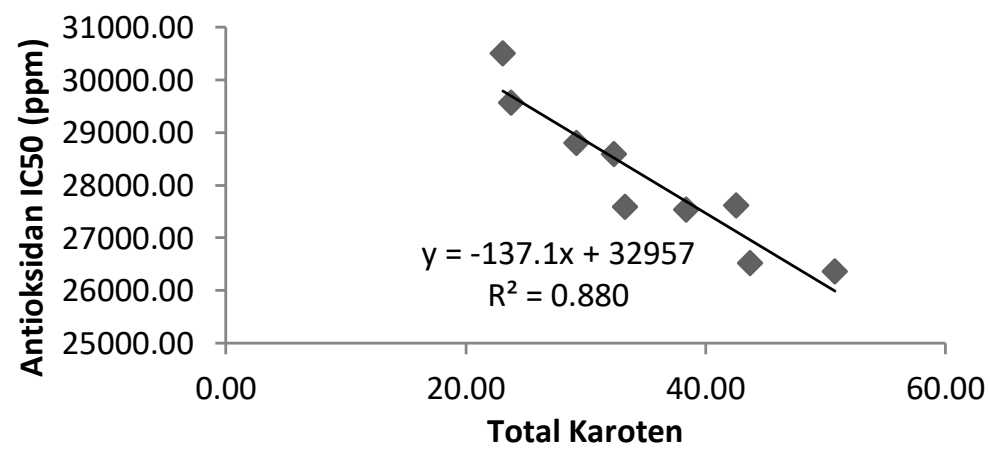

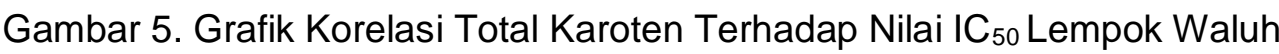


Korelasi menunjukkan bahwa semakin tinggi nilai total karoten lempok waluh maka akan semakin kecil nilai $\mathrm{IC}_{50}$ lempok waluh. Karoten termasuk dalam golongan karotenoid yang dapat berperan sebagai antioksidan. Kandungan karoten yang besar akan mempengaruhi kemampuan bahan tersebut dalam menangkap radikal bebas.

\section{Tekstur Lempok Waluh}

Hasil sidik ragam menunjukkan bahwa perlakuan penambahan proporsi maizena:slurry dan lama pemasakan memberikan pengaruh yang sangat nyata tekstur lempok waluh $(\alpha=0.01)$, sedangkan interaksi antara kedua faktor tidak berpengaruh nyata. Rerata tekstur lempok waluh akibat perlakuan proporsi maizena:slurry dan lama pemasakan yang berbeda dapat dilihat pada Gambar 6.

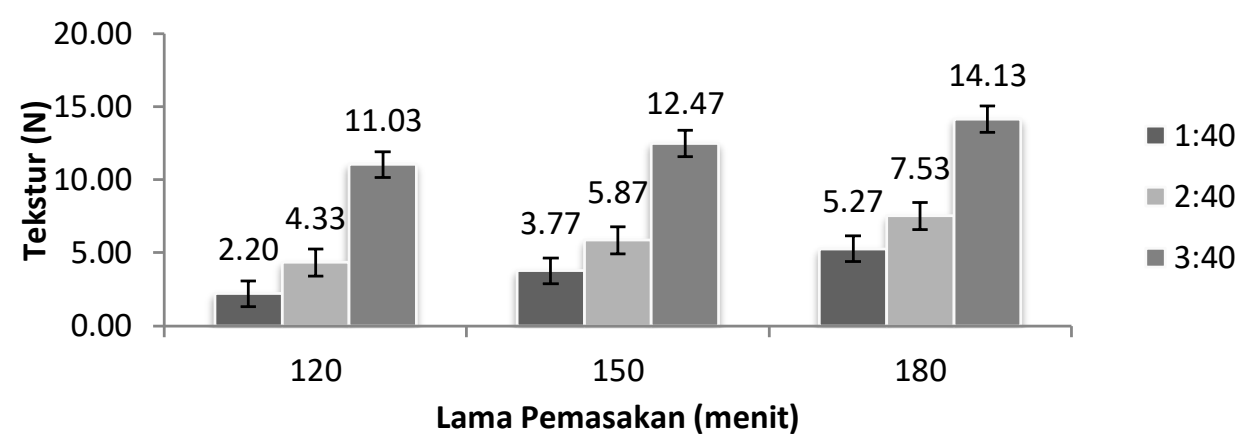

Gambar 6. Grafik Rerata Tekstur (N) Lempok Waluh Akibat Pengaruh Penambahan Proporsi Maizena:Slurry dan Lama Pemasakan Lempok

Gambar 6 menunjukkan bahwa semakin banyak proposi maizena yang ditambahkan, maka tekstur akan semakin keras. Hal ini dikarenakan pada saat pemanasan pati pada maizena akan tergelatinisasi sehingga terjadi pembengkakan granula pati yang dapat membentuk tekstur yang kompak (Winarno, 2008). Sedangkan semakin lama pemasakan lempok waluh, maka tekstur lempok waluh akan semakin keras dikarenakan pada ketika pemanasan terjadi penguapan air yang dapat menyebabkan viskositas produk menjadi meningkat. Selain itu tekstur juga dipengaruhi oleh kadar air di dalam bahan, adapun korelasi antara kadar air dengan tekstur lempok waluh dapat dilihat pada Gambar 7.

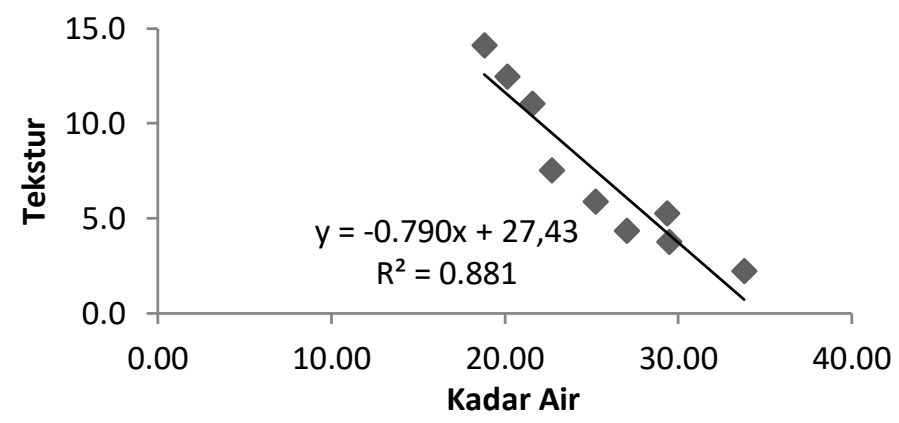

Gambar 4.7 Grafik Korelasi Kadar Air Terhadap Tekstur Lempok Waluh

Korelasi menunjukkan bahwa semakin tinggi kadar air lempok waluh maka semakin tinggi nilai teksturnya atau semakin keras tesktur lempok waluh. Kadar air yang tinggi menyebabkan pektin banyak menarik air. Ketika air yang ditahan struktur besar, maka gel tidak dapat mempertahankan struktur, sedangkan jika air yang ditahan oleh struktur sedikit maka tekstur akan lebih kompak dan kokoh. 


\section{Warna Lempok Waluh}

a. Kecerahan $\left(L^{*}\right)$

Nilai L menunjukkan tingkat kecerahan sampel. Semakin cerah sampel yang diukur maka nilai $L$ mendekati 100 . Hasil sidik ragam menunjukkan bahwa perlakuan lama pemasakan memberikan pengaruh yang sangat nyata terhadap rerata nilai kecerahan lempok waluh $(\alpha=0.01)$, sedangkan perlakuan proporsi maizena:slurry serta interaksi antar kedua faktor tidak berpengaruh nyata. Rerata nilai kecerahan $\left(L^{*}\right)$ lempok waluh akibat perlakuan proporsi maizena:slurry dan lama pemasakan yang berbeda dapat dilihat pada Gambar 8.

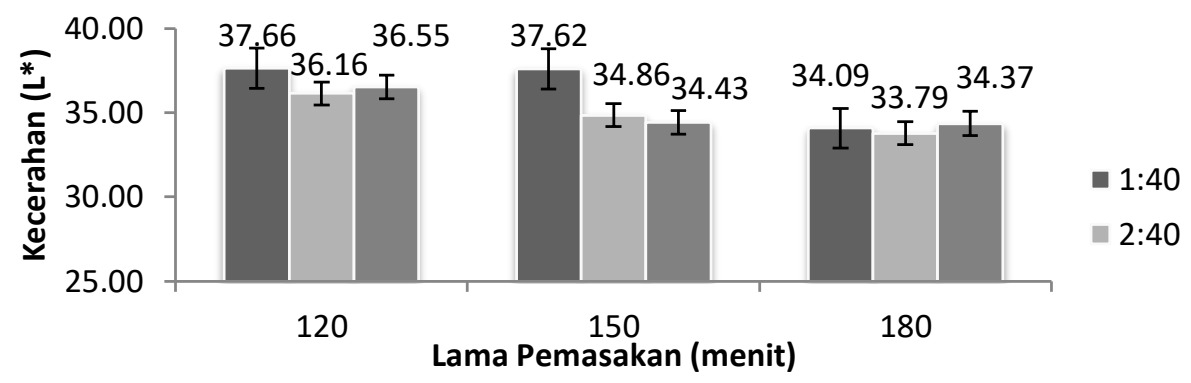

Gambar 8. Grafik Rerata Nilai Kecerahan ( $\left.L^{*}\right)$ Lempok Waluh Akibat Pengaruh Penambahan Proporsi Maizena:Slurry dan Lama Pemasakan Lempok

Gambar 8 menunjukkan bahwa semakin lama proses pemasakan lempok, maka nilai kecerahan pada lempok waluh akan menurun atau semakin gelap. Hal ini dikarenakan pada proses pembuatan lempok waluh melibatkan proses panas yang dapat menyebabkan terjadinya browning non enzimatis seperti terjadinya reaksi Maillard dan karamelisasi. karamelisasi ini sering terjadi pada proses pengolahan dengan pemanasan. Reaksi Maillard merupakan reaksi antara gugus amino dari suatu asam amino bebas residu rantai peptida atau protein dengan gugus karbonil dari suatu karbohidrat apabila keduanya dipanaskan (Lakshmi, 2014). Selain itu penambahan gula, menurut Adiono dan Purnomo (2007), pada produk yang diberi penambahan gula pada pembuatan lempok waluh menyababkan teradinya proses karamelisasi Karamel yang terbentuk selama pemanasan memberi warna coklat pada produk pangan.

\section{b. Kemerahan $\left(a^{*}\right)$}

Nilai kemerahan $\left(a^{*}\right)$ merupakan parameter warna yang menunjukkan tingkat warna merah suatu produk. Skala nilai $a^{*}$ yaitu -100 hingga 100 yang menyatakan tingkat warna hijau hingga merah (Pomeranz dan Meloan, 1994). Hasil sidik ragam menunjukkan bahwa perlakuan penambahan proporsi maizena:slurry dan lama pemasakan memberikan pengaruh yang sangat nyata terhadap nilai kemerahan lempok waluh $(\alpha=0.01)$, sedangkan interaksi antara kedua faktor tidak berpengaruh nyata. Rerata nilai kemerahan $\left(a^{*}\right)$ lempok waluh akibat perlakuan proporsi maizena:slurry dan lama pemasakan yang berbeda dapat dilihat pada Gambar 9.

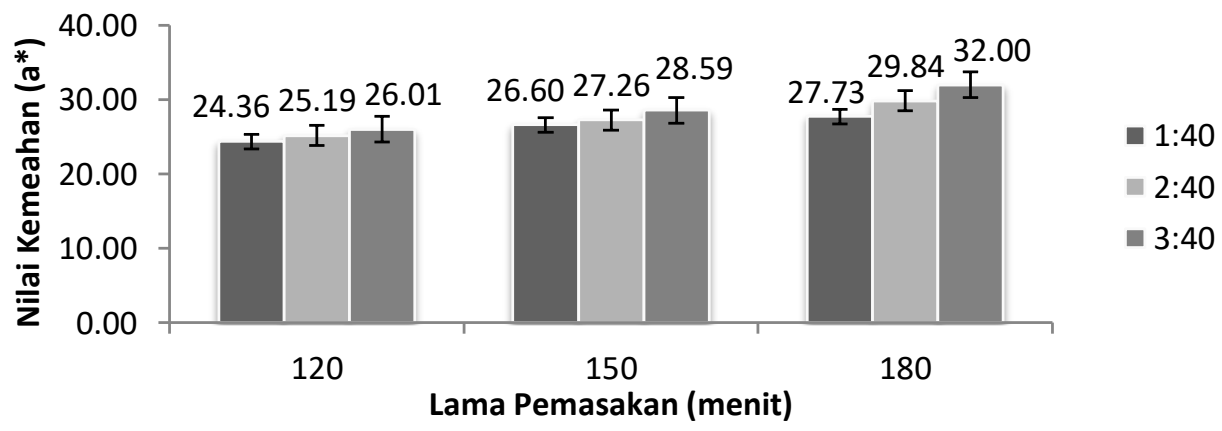

Gambar 9. Grafik Rerata Nilai Kemerahan (a*) Lempok Waluh Akibat Pengaruh

Penambahan Proporsi Maizena:Slurry dan Lama Pemasakan Lempok 
Gambar 9 menunjukkan bahwa semakin banyak proposi maizena, maka nilai kemerahan akan menurun dikarenakan warna dari maizena sendiri adalah putih, sehingga akan membuat warna semakin pucat atau pudar. Sedangkan semakin lama pemasakan lempok waluh, maka nilai kemerahan pada lempok waluh akan meningkat dikarenakan terjadinya proses pencoklatan (Adiono dan Purnomo, 2007).

\section{c. Kekuningan $\left(b^{\star}\right)$}

Nilai kekuningan $\left(b^{*}\right)$ menyatakan tingkat warna biru sampai kuning dengan kisaran nilai -100 sampai +100 . Nilai negatif $(-)$ menyatakan kecenderungan warna biru sedangkan nilai positif (+) menyatakan warna kuning. Hasil sidik ragam menunjukkan perlakuan lama pemasakan memberikan pengaruh yang sangat nyata terhadap rerata nilai kekuningan lempok waluh $(\alpha=0.01)$, sedangkan perlakuan proporsi maizena:slurry serta interaksi antar kedua faktor tidak berpengaruh nyata. Rerata nilai kekuningan $\left(b^{*}\right)$ lempok waluh akibat perlakuan proporsi maizena:slurry dan lama pemasakan yang berbeda dapat dilihat pada Gambar 10.

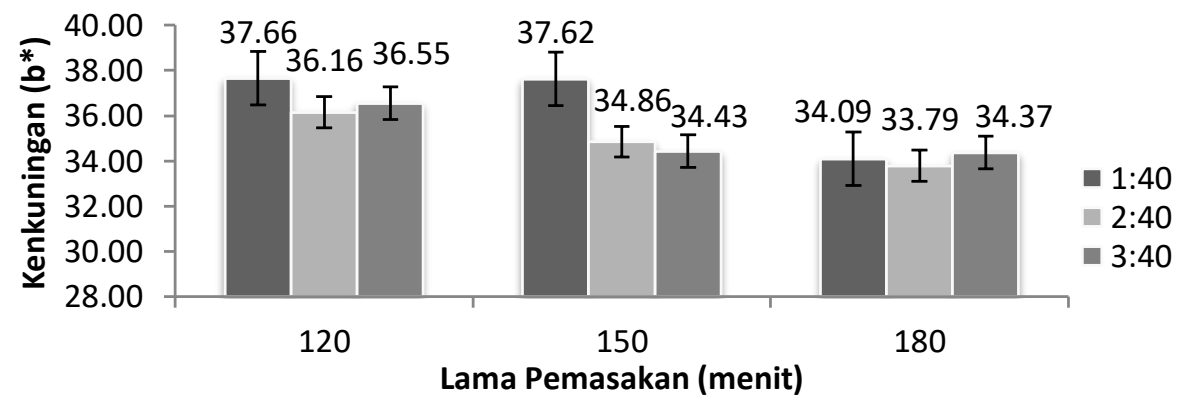

Gambar 10. Grafik Rerata Nilai Kekuningan ( $\left.b^{\star}\right)$ Lempok Waluh Akibat Pengaruh Penambahan Proporsi Maizena:Slurry dan Lama Pemasakan Lempok

Gambar 10 menunjukkan bahwa semakin lama pemasakan lempok waluh, maka nilai kekuningannya akan semakin menurun. Hal ini dikarenakan karotenoid yang tidak stabil pada suhu tinggi. Karotenoid dapat mengalami degradasi selama pengolahan karena proses oksidasi pada suhu tinggi yang mengubah senyawa karotenoid menjadi senyawa ionon berupa keton (Histifarina dkk, 2004).

\section{Organoleptik Lempok Waluh}

Hasil pengamatan terhadap parameter warna, aroma, rasa, dan tekstur semua perlakuan lempok waluh dapat diamati pada Gambar 11. Berdasarkan Gambar 11 dapat dilihat bahwa proporsi maizena:slurry dan lama pemasakan lempok waluh cenderung menghasilkan mutu organoleptik yang menjauhi pusat. Semakin menjauhi titik pusat maka respon panelis terhadap mutu organoleptik lempok lempok waluh dengan perlakuan proporsi maizena:slurry dan lama pemasakan semakin tinggi atau produk dapat diterima oleh panelis. Lempok waluh dengan perlakuan proporsi maizena:slurry sebanyak 2:40 dengan lama pemasakan 180 menit memberikan penilaian yang paling baik terhadap mutu organoleptik lempok waluh tersebut,hal tersebut mengindikasikan bahwa panelis lebih menyukai lempok dengan perlakuan tersebut. 


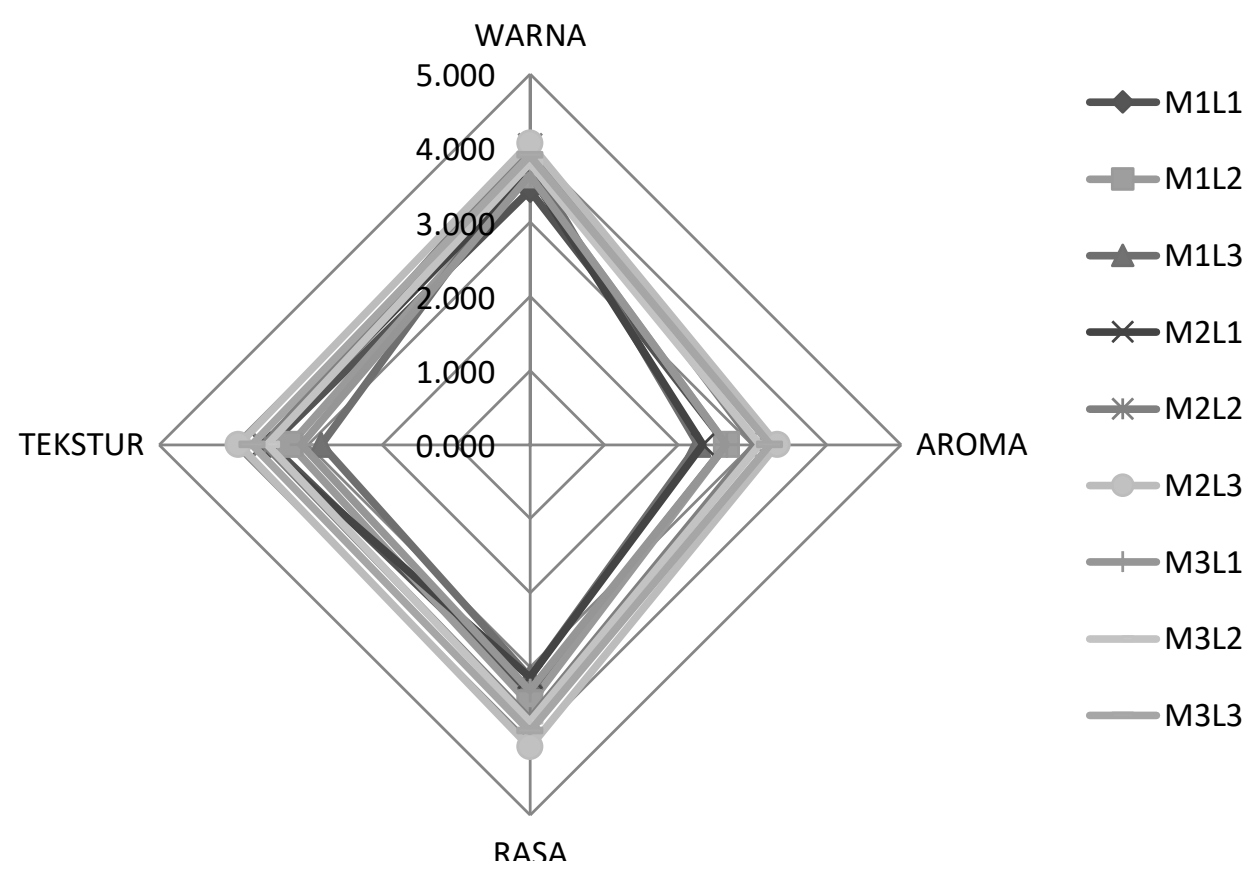

Gambar 11 Grafik Rerata Hasil Uji Hedonik 9 Perlakuan Terhadap Parameter Warna, Aroma, Rasa dan Tekstur Pada Lempok Waluh

\section{Perlakuan Terbaik}

Pemilihan perlakuan terbaik diperoleh melalui perhitungan menggunakan metode multiple attribute menurut Zeleny (1982) dengan prosedur pembobotan sesuai nilai ideal pada masing-masing parameter. Penentuan perlakuan terbaik parameter kimia dan fisik lempok waluh yaitu kadar air, total gula, total karoten, aktivitas antioksidan, tekstur, dan warna. Hasil pengujian terbaik lempok waluh terhadap parameter kimia, fisik dan organoleptik dapat dilihat pada Tabel 2.

Tabel 2 Perlakuan Terbaik Parameter Kimia, Fisik dan Organoleptik Lempok Waluh Akibat Perlakuan Proporsi maizena:slurry dan Lama Pemasakan

Perlakuan

\section{Nilai L Total Terendah} (Metode Zeleny)

$\begin{array}{ll}\text { Maizena:slurry 1:40 lama pemasakan 120 menit } & 0.3685 \\ \text { Maizena:slurry 2:40 lama pemasakan 150 menit } & 0.3641 \\ \text { Maizena:slurry 3:40 lama pemasakan 180 menit } & 0.4048 \\ \text { Maizena:slurry 1:40 lama pemasakan 120 menit } & 0.2985 \\ \text { Maizena:slurry 2:40 lama pemasakan 150 menit } & 0.2747 \\ \text { Maizena:slurry 3:40 lama pemasakan 180 menit } & 0.2829 \\ \text { Maizena:slurry 1:40 lama pemasakan 120 menit } & 0.2369 \\ \text { Maizena:slurry 2:40 lama pemasakan 150 menit } & 0.2259 * \\ \text { Maizena:slurry 3:40 lama pemasakan 180 menit } & 0.2303\end{array}$

Keterangan : $\left(^{*}\right)$ Perlakuan Terbaik

Pada Tabel 2 dapat diketahui bahwa berdasarkan seluruh parameter baik secara kimia, fisik dan organoleptik maka lempok dengan perlakuan proporsi maizena:slurry 3:40 dengan lama pemasakan 150 menit menghasilkan lempok dengan perlakuan terbaik. Hal ini 
dikarenakan sebagian karakteristik secara kimia,fisik, dan organoleptik yang diinginkan sesuai dengan perlakuan tersebut.

\section{SIMPULAN}

Perlakuan proporsi maizena:slurry berpengaruh sangat nyata $(\alpha=0.01)$ terhadap kadar air, total gula, total karoten, tekstur, tingkat kemerahan $\left(a^{*}\right)$, warna organoleptik, aroma organoleptik, rasa organoleptik, dan tekstur organoleptik. Perlakuan lama pemasakan berpengaruh sangat nyata $(\alpha=0.01)$ terhadap kadar air, total gula, total karoten, antioksidan $\mathrm{IC}_{50}$, tekstur, tingkat kecerahan $\left(\mathrm{L}^{*}\right)$, tingkat kemerahan $\left(\mathrm{a}^{*}\right)$, tingkat kekuningan $\left(\mathrm{b}^{*}\right)$, warna organoleptik, aroma organoleptik, rasa organoleptik, dan tekstur organoleptik. Interaksi antara perlakuan proporsi maizena:slurry dan lama pemasakan berpengaruh sangat nyata $(\alpha=0.01)$ terhadap kadar air lempok waluh. Perlakuan terbaik lempok waluh menurut parameter kimia, fisik dan organoleptik yaitu pada perlakuan proporsi maizena:slurry 3:40 dengan lama pemasakan 150 menit.

\section{DAFTAR PUSTAKA}

Adiono, dan Purnomo. 2007. Ilmu Pangan. Universitas Indonesia-Press, Jakarta

Sari, M. 2011. Maizena Sebagai Alternatif Pengganti Pektin Dalam Pembuatan Selai Belimbing. Jurnal Sainstek 3:1, 44-51

Histifarina, D., Musaddad, D., dan Murtiningsih, E., 2004, Teknik Pengeringan dalam Oven Untuk Irisan Wortel Kering Bermutu. Jurnal Hortikultura 14:2, 107-112

Husni, Deffy, R., Putra, dan Lelana, I. 2014. Aktivitas Antioksidan Padina Sp. Pada Berbagai Suhu Dan Lama Pengeringan. Jurnal Perikanan 9:2, 165-173

Imanningsih, N. 2012. Profil Gelatinisasi beberapa Formulasi Tepung-tepungan untuk Pendugaan Sifat Pemasakan. Penel Gizi Makan. 35:1, 13-22.

Jariyah, Nurismanto, dan Sudaryati, 2017. Produksi Sirup Glukosa Hasil Hidrolisis Enzimatis Pati Garut. Skripsi. UPN Veteran. Surabaya

Jaswir, I., Noviendri, D., Hasrini, R.F. and Octavianti. 2011. Carotenoids: Source, Medicinal Properties and Their Application in Food and Nutraceutical Industry. Journal of Medicinal Plants Research 5:33, 22-26

Kusumawati, D.A. 2013. Karakteristik Fisik dan Kimia Edible Film Pati Jagung yang Diinkorporasi dengan Perasan Temu Hitam. Jurnal Pangan dan Agroindustri 2:1, 90100

Lakshmi, C. 2014. Food Coloring: The Natural Way. Journal of Chemical Sciences 4:1, 8796

Madalena, Heriyanto, Hastuti, S.P. dan Limantara, L., 2007. Pengaruh Lama Pemanasan Terhadap Kandungan Pigmen serta Vitamin A Daun Singkong (Manihot esculenta Crantz) dan Daun Singkong Karet (Manihot glaziovii Muell. Arg). Journal Chemistry 7:1, 97-104

Murdiati, A., Gardjito, M., dan Noor, Z. 1989. Produksi Campuran Tepung kaya Vitamin A dan Kajian Sifat-Sifatnya. Fakultas Teknologi Pertanian. Universitas Gadjah Mada. Yogyakarta

Pomeranz and Meloan, 1994: Food Analysis; Theory and Practice. Chapman \& Hall, New York

Wahyuni, D.T., dan Widjanarko, S.B. 2015. Pengaruh Jenis Pelarut dan Lama Ekstraksi Terhadap Ekstrak Karotenoid Labu Kuning Dengan Metode Gelombang Ultrasonik. Jurnal Pangan dan Agroindustri 3:2, 390-401

Winarno, F.G. 2008. Kimia Pangan dan Gizi Edisi Terbaru. Embrio Biotekindo. Bogor

Yuliani, Usmiati, Styaningsih, dan Maria O.G. 2005. Karakteristik Serbuk Labu Kuning (Cucurbita moschata). Jurnal Teknologi dan Industri Pangan. 16:2, 157-167

Zeleny, M. 1982. Multiple Criteria Decision Making. Mc Graw-Hill Co. New York 